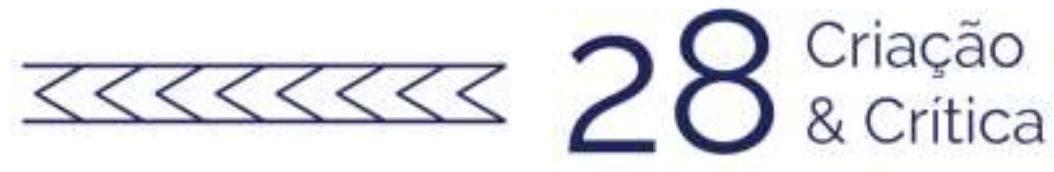

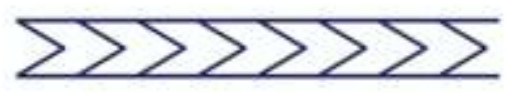

\section{TRÊS POEMAS DE PROCURA}

João Mostazo ${ }^{1}$

\section{A BÚSSOLA}

Procuro uma bússola - procuro

ou procuro inventar uma bússola?

Uma bússola que eu encontre na areia, batendo como um relógio, como um coração,

só que máquina, só que automática, nem viva nem morta, igual a todas, só que única.

Uma bússola, essa, que seja enfática e não me deixe hesitar, eu mesmo, que vago,

e que me leve, de erro em erro, pra mais perto de todo certo, de todo símbolo.

Uma bússola máxima, e complexa, e profundamente simples, e mínima

e ínfima, e inédita, e que infrinja, repentina, o tamanho do bolso.

E mesmo que seja só a agulha, e que a agulha nem seja agulha,

não seja nada, seja uma fenda, uma cicatriz aberta e móvel,

oscilando sozinha no espaço, aberta no ar, no medo,

uma linha de vácuo simpático, determinada, definitiva, irreversível,

\footnotetext{
${ }^{1}$ Bacharel em Estudos Literários pela Unicamp, doutorando no programa de Teoria Literária e Literatura Comparada da FFLCH/USP - São Paulo.
} 
e ainda que nem seja uma bússola, sem imã, sem agulha, sem estrela,

ainda que seja uma lâmpada,

uma boca, uma música, uma revolta,

uma seta riscada no chão,

que seja qualquer outra coisa,

um dedo de pedra decepado

apontando em qualquer direção,

o que importa é que indique o norte

pra mim igual pra você. 


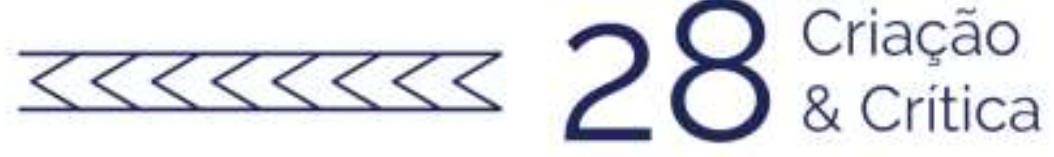

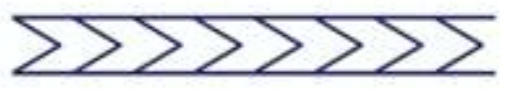

\section{O MESOPOTÂMIO}

Pensa no mesopotâmio e pensa

que deviam ir juntos,

mas não sabe pra onde. Pensa no mesopotâmio,

no egípcio, no fenício,

no mesozoico absurdo, no paleolítico

cuja mão queimou todas as cavernas do mundo. Pensa

no grego pré-helênico, heroico, e no troiano

e no romano; pensa na babilônica Enheduanna,

sua ancestral, sua contemporânea.

Pensa nos índios americanos antes dos cavalos, pensa nos índios mexicanos antes da varíola, pensa nos índios brasileiros antes do espelho.

Mas pensa sobretudo no mesopotâmio da idade do bronze tardia, no primeiro fim do mundo.

Você e ele, o mesopotâmio,

deviam ir juntos - pra onde, eu não sei.

Em que língua eu não sei, dizer ao mesopotâmio que é uma pena, tudo isso.

Se ele te desse a mão? A mão tão real quanto a sua, tão perdida, tão por acaso quanto a sua.

Pensa no mesopotâmio na borda das trevas.

Pensa nisso e pensa em si mesmo, e pensa de quem, de que planeta, de que século cinquenta é você o mesopotâmio.

Devia ir junto com o mesopotâmio visitar o século cinquenta, o quinto milênio, o último dia da terra antes de todo o resto. 


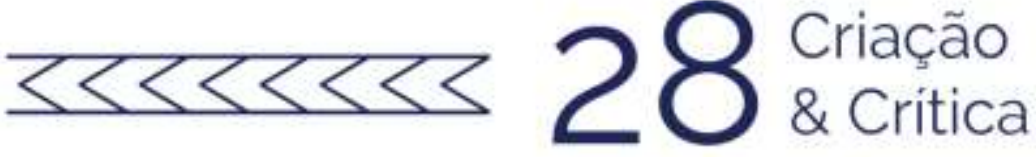

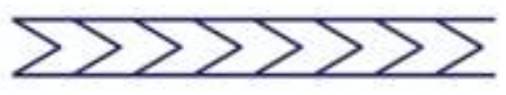

SE SOUBÉSSEMOS DIRÍAMOS MELHOR

Essa gente, parece,

é mais caroço do que gente.

Quase esquece, quase vive

automaticamente.

Gente que na casca carrega

a marca, a ferro: existe.

Gente com a casca marcada, gente triste.

Gente, como toda, com alma;

na alma, seus corpos, seus mundos,

mundos caroços, fechados,

duros, fecundos.

Dentro, no fundo, no oco, ou nem no fundo ainda, sabe onde vai, de onde veio? Essa gente que é vida, que é vinda.

Essa gente, homem, mulher, enigma a céu aberto, tão longe de ser o que quer, tão perto.

Essa gente onde o ser se cumpre, cumprida, ainda presente, tipo um fósforo queimado: tão igual, tão diferente.

Tipo um fósforo queimado: tão pouco.

Tão pouco, tipo uma árvore queimada não parece uma árvore, não parece mais nada.

A nós, que vivemos livres nesta arena compulsória, a nós, que vivemos juntos, quase presos na memória, 


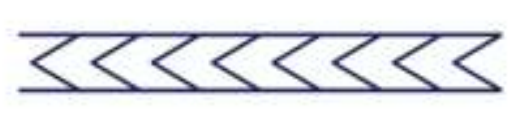

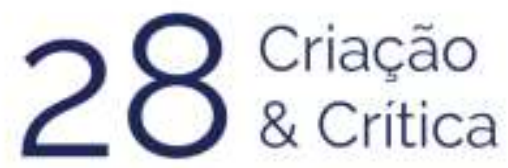

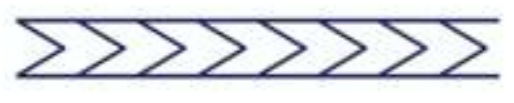

a nós, essa gente que fala e que um dia se cala num lance fatal escreve e expira, defunta o medo, seu fóssil, pergunta:

a verdade era oral?

Recebido em: 18/07/2020

Aceito em: 18/07/2020

Referência eletrônica: LOPES, João Gabriel Mostazo. Três poemas de procura. Criação \& Crítica, n. 28, p., dez. 2020. Disponível em: <http://revistas.usp.br/criacaoecritica>. Acesso em: dd mmm. aaaa. 